Journal of Clinical Investigation

Vol. 42, No. 1, 1963

\title{
A STUDY OF FIBRINOGEN PRODUCTION BY HUMAN LIVER SLICES IN VITRO BY AN IMMUNOPRECIPITIN METHOD
}

\author{
By P. WERNER STRAUB * \\ (From the Service of Medicine and Clinical Investigation, Institut Jules Bordet, Centre Anti- \\ cancereux de l'Université Libre de Bruxelles, Belgium)
}

(Submitted for publication July 17, 1962; accepted September 25, 1962)

There have been numerous experiments based on hepatectomy or acute liver intoxication indicating that the liver is the organ responsible for the manufacture of blood fibrinogen in dogs (1, 2 ) and rabbits (3). Perfusion experiments on rats (4) confirmed the role of the liver in the production of fibrinogen as well as of other plasma proteins except gamma globulins.

Up to now, however, no demonstration was given that liver tissue could manufacture fibrinogen in vitro, despite the fact that in vitro techniques with liver tissue were used to demonstrate the production of serum proteins in the chicken and in the rat (5-7). These studies were based on immunological methods for the detection and measurement of serum proteins.

The demonstration by Gitlin and Borges (8) that immunoprecipitin methods are able to detect minute amounts of fibrinogen, as are found in patients with so-called afibrinogenemia, suggested that these methods could be used in a study of the production of fibrinogen by human liver slices in vitro. Such production, under the ordinary conditions of in vitro tissue incubation, would be expected to be small and amenable to demonstration only insofar as a sensitive and yet precise method of measurement was employed. The interesting method described by Hochwald, Thorbecke, and Asofsky (9) unfortunately does not lend itself to quantitative purposes.

The present work provides evidence that when fresh human liver slices are incubated in vitro, there is a significant increase in the amount of extractable fibrinogen at the end of the incubation period as compared with the amount at the beginning of the incubation period.

\section{MATERIALS AND METHODS}

Human fibrinogen. Fraction I of Cohn was used. This fraction contained $7 \mathrm{~g}$ of fibrinogen and $5 \mathrm{~g}$ of other

* Present address : Department of Medicine, Kantonsspital, University of Zurich, Switzerland. proteins (Poviet Producten, Amsterdam, Netherlands). Heparin. Liquemin Roche assaying 5,000 U per ml was used.

Krebs-Ringer bicarbonate solution was prepared according to P. P. Cohen (10). To $500 \mathrm{ml}$ of the final solution $0.1 \mathrm{ml}$ of heparin was added.

L-leucine- $C^{14}$. The L-leucine- $\mathrm{C}^{14}$ hydrochloride, Batch $40(0.02 \mathrm{mg}=1 \mu \mathrm{c})$ of The Radiochemical Center, Amersham, England, was used.

L-leucine. The L-leucine of Sigma Laboratory was used.

Preparation of antihuman fibrinogen-antibodies. This was done according to the technique of Gitlin (11).

The antiserum of three adult rabbits was absorbed three times with 1\%, vol of pooled normal human serum in order to remove impurities of antiserum protein antibodies. It was then precipitated at $0^{\circ} \mathrm{C}$ with an equal volume of saturated ammonium sulfate. The precipitate was spun down at $3,000 \mathrm{rpm}$ at $5^{\circ} \mathrm{C}$, dissolved in saline and dialyzed during 3 days in the cold room with frequent changes of saline containing $1 \mathrm{U}$ of heparin per $\mathrm{ml}$. The antibody solution was then centrifuged for 1 hour at 4,000 rpm, and the supernate was divided into 5-ml lots and stored at $-20^{\circ} \mathrm{C}$.

This solution did not clot an equal volume of rabbit oxalated plasma in 48 hours. It formed a flocculent precipitate with human plasma. As determined by precipitation curve and Kjehldahl nitrogen-determination of the precipitate, it contained 0.3 to $0.4 \mathrm{mg}$ of antihuman fibrinogen-antibody per $\mathrm{ml}$.

The specificity of the antibody solution was tested on the double diffusion plate of Ouchterlony (12), with 1 per cent Difco Agar "Noble" 0142-01 in phosphate buffer $0.11 \mathrm{M}, \mathrm{pH}$ 7.4. Normal human serum $1 / 10$ diluted, normal human plasma $1 / 10$ diluted, Cohn's fraction I (containing $25 \mathrm{mg}$ per cent fibrinogen), and tissue extract were introduced in peripheral holes of $8 \mathrm{~mm}$ diameter. The antibody solution was placed into a central hole and the plates incubated at $37^{\circ} \mathrm{C}$. Only one precipitation line was found with plasma. No cross-reaction occurred with serum proteins (Figure 1A). Figure 1B corresponds to experiment 4. Precipitation lines are found with two nonincubated lots as well as with two incubated lots. In all the other experiments, the antigen concentration in the nonincubated lots was not sufficient to produce a precipitation line, and a definite line was found only with the incubated lots. In Figure $1 \mathrm{~B}$ a faint second line can be observed near the right lower antigen well. In the right 

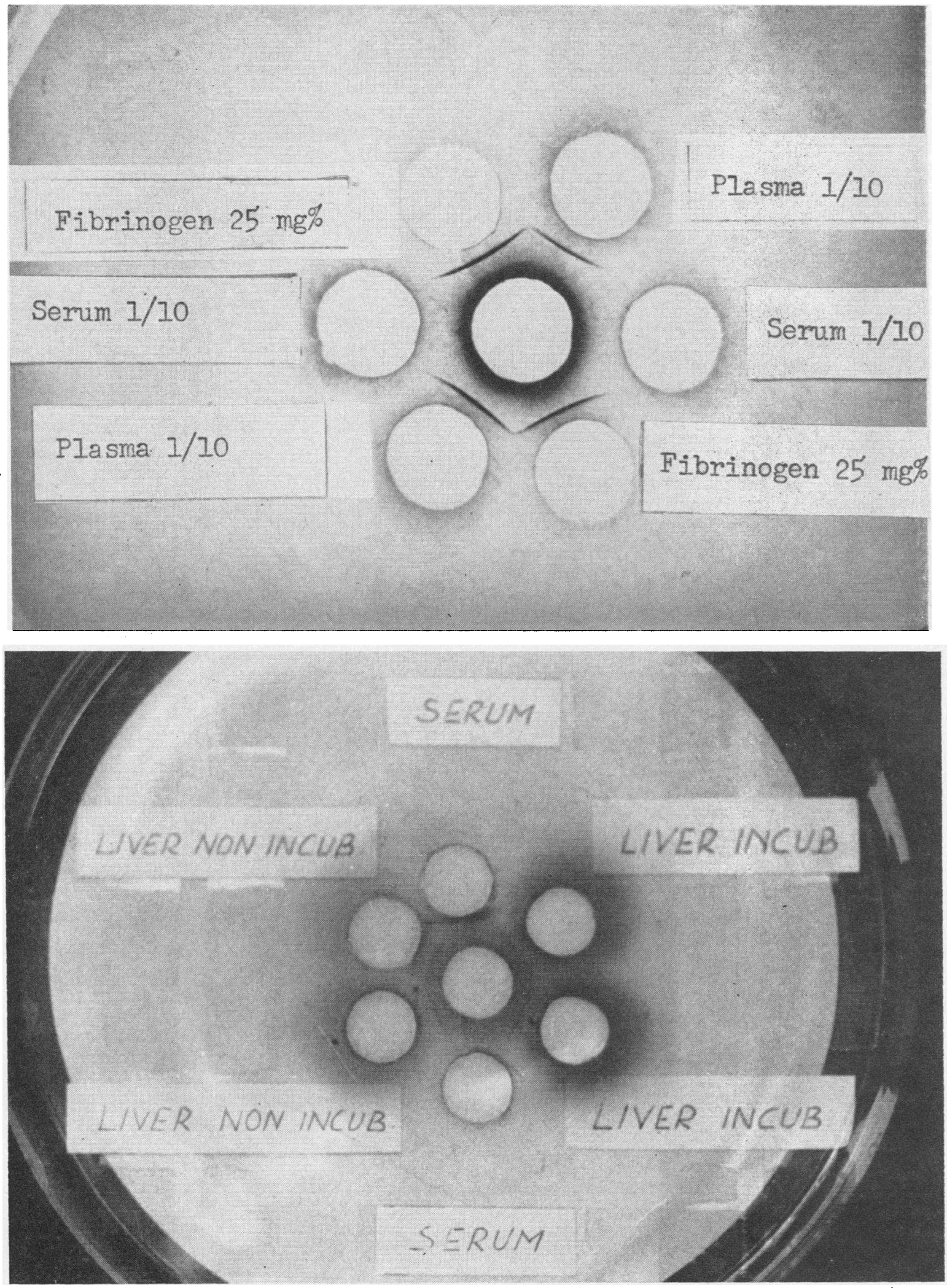

Fig. 1, A and b. Double diffusions patterns of antihuman-Fibrinogen antibody verst's human serum, huma FLASMA, AND HUMAN LIVER EXTRACT. 
upper well, which shows a lot of the same experiment, this line is absent and it has not been observed in any other experiment. It is thought to be an artifact produced by a dirt particle at that plate. The possibility of another antigen, however, will be discussed below.

Procedure. Liver specimens were obtained at laparotomy from the patients listed below:

Experiment 1. Patient M.D., case report no. 16481, generalized mammary carcinoma. Bilateral ovariectomy.

Experiment 2. Patient O.G., case report no. 25265, gangrenous cholecystitis. Cholecystostomy.

Experiment 3. Patient R.C., case report no. 19511, suspicion of renal carcinoma. Diagnostic laparotomy (Hospital St. Pierre, Brussels).

Experiment 4. Patient F.M., case report no. 18372, adenocarcinoma of the colon. Resection.

Experiment 5. Patient S.G., case report no. 23091, generalized mammary carcinoma. Bilateral ovariectomy.

Experiment 6. Patient O. van L., case report no. 25181, epithelioma of the posterior vaginal wall. Pelvectomy.

Experiment 7. Patient A.L., case report no. 20311, generalized mammary carcinoma. Bilateral ovariectomy.

In no case could liver metastasis be detected at laparotomy. Histological examination of the liver specimen revealed a normal structure.

Liver tissue in amounts of approximately $1 \mathrm{~g}$ to $2.5 \mathrm{~g}$ was immersed immediately after removal in ice-cold heparinized Krebs-Ringer bicarbonate solution at $\mathrm{pH} 7.4$ and equilibrated with an atmosphere of 95 per cent $\mathrm{O}_{2}$ and 5 per cent $\mathrm{CO}_{2}$. The tissue specimen was decapsulated and cut into two pieces. Samples of tissue at the cut section were taken for histological examination. The following steps were carried out in the cold room at $2^{\circ} \mathrm{C}$. Thin slices were cut by hand with a razor blade and suspended in the Krebs-Ringer bicarbonate solution. The slices were washed eight times in 50-ml portions of solution for approximately 15 to 20 minutes. This was done in order to remove as much of the fibrinogen present in the tissue as possible. The slices were randomly distributed in equal lots of 150 to $450 \mathrm{mg}$ each, the size of the lots depending on the amount of tissue available. Each lot was suspended in a Warburg flask containing $5 \mathrm{ml}$ of the heparinized Krebs-Ringer bicarbonate solution. The flasks were gassed for 10 minutes with the $\mathrm{O}_{2}-\mathrm{CO}_{2}$ mixture. In most experiments three lots were left in the cold room while three other lots were incubated for 4 hours at $37^{\circ} \mathrm{C}$ in the Warburg apparatus with shaking at the rate of 100 per minute.

At the end of the incubation period the flasks were rapidly cooled in an ice-bath. The content of each flask, incubated as well as nonincubated, was homogenized in the cold room $\left(2^{\circ} \mathrm{C}\right)$ by a Potter-type homogenizer for 3 minutes at the rate of 10 revolutions per second. Care was taken to avoid bubble formation. The tube and the pistil were rinsed with $1 \mathrm{ml}$ of Krebs-Ringer bicarbonate solution. Microscopic examination of a smear of the final homogenate showed absence of intact cells.

The homogenates from each flask were kept separate and centrifuged for 90 minutes at $20,000 \mathrm{~g}$ at $5^{\circ} \mathrm{C}$. The

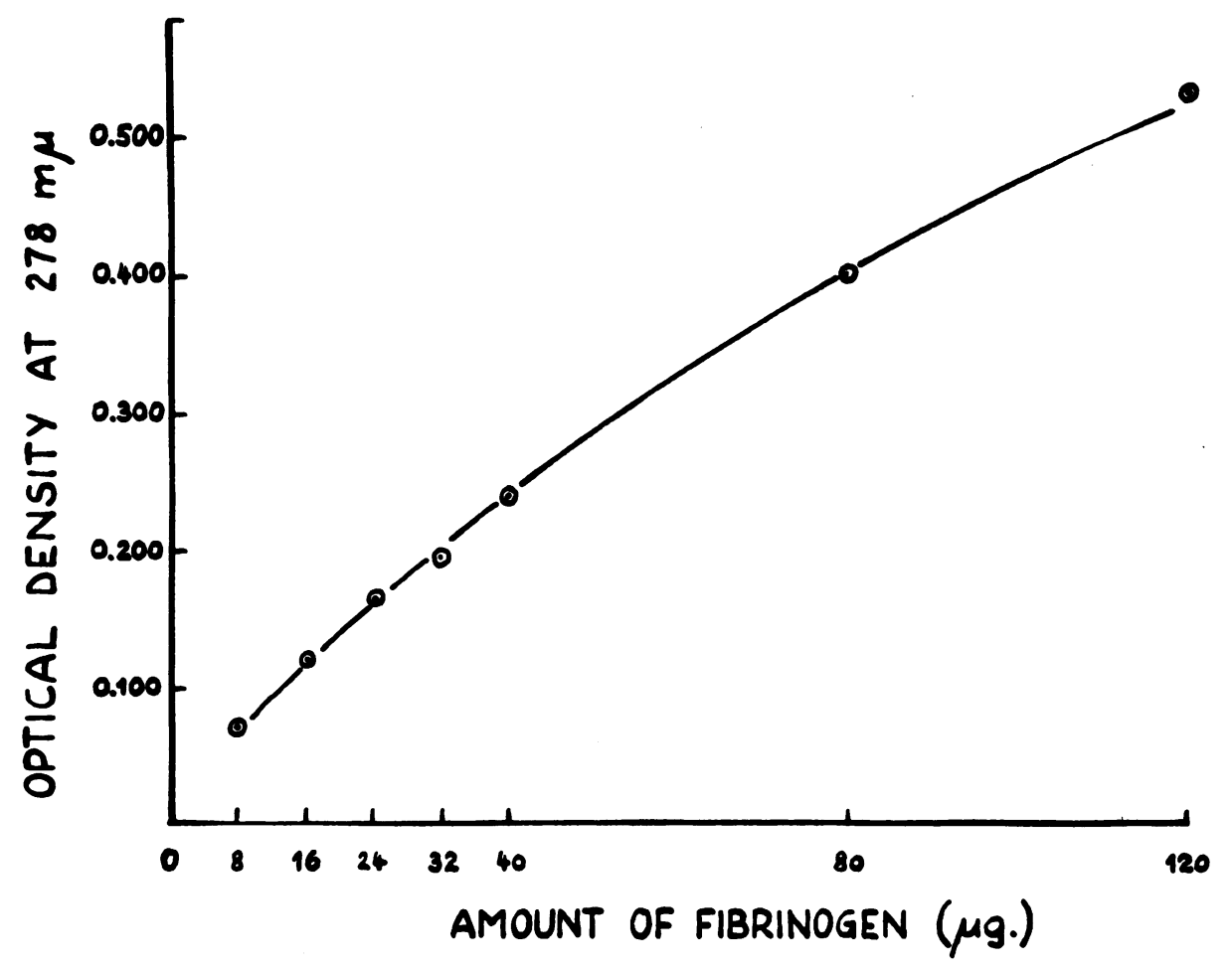

Fig. 2. Standard CURve for estimation of Fibrinogen. 
TABLE I

Increase of antibody-precipitated protein after incubation

\begin{tabular}{|c|c|c|c|c|c|}
\hline \multirow{3}{*}{$\begin{array}{c}\text { Experi- } \\
\text { ment }\end{array}$} & \multicolumn{2}{|c|}{$\begin{array}{l}\text { Micrograms of antibody- } \\
\text { precipitated protein per } \\
\text { gram liver tissue } \\
\end{array}$} & \multicolumn{3}{|c|}{$\begin{array}{l}\text { Results of statistical one-factor analysis of } \\
\text { variance af ter logarithmic transformation } \\
\text { of the original data }\end{array}$} \\
\hline & \multirow{2}{*}{$\begin{array}{l}\text { Nonincu- } \\
\text { bated lots }\end{array}$} & \multirow{2}{*}{$\begin{array}{c}\text { Incubated } \\
\text { lots }\end{array}$} & \multirow{2}{*}{$\begin{array}{l}\text { Fobserved } \\
\text { (Snedecor) }\end{array}$} & \multicolumn{2}{|c|}{$\begin{array}{c}\text { Degrees of } \\
\text { freedom }\end{array}$} \\
\hline & & & & $\overline{n_{1}}$ & $\overline{n_{2}}$ \\
\hline 1 & $\begin{array}{l}6.5 \\
4.0 \\
4.0\end{array}$ & $\begin{array}{r}97.2 \\
87.2 \\
100.0\end{array}$ & $322.6^{*}$ & 1 & 4 \\
\hline 2 & $\begin{array}{l}3.2 \\
6.5\end{array}$ & $\begin{array}{l}41.0 \\
17.5\end{array}$ & 10.2 & 1 & 2 \\
\hline 3 & 57.6 & $\begin{array}{l}248.8 \\
124.8\end{array}$ & & & \\
\hline 4 & $\begin{array}{l}140.0 \\
226.0 \\
119.0\end{array}$ & $\begin{array}{l}556.0 \\
428.0 \\
508.0\end{array}$ & $31.15 \dagger$ & 1 & 4 \\
\hline 5 & $\begin{array}{l}38.7 \\
26.7 \\
38.7\end{array}$ & $\begin{array}{r}138.5 \\
119.3 \\
94.4\end{array}$ & $53.84 \dagger$ & 1 & 4 \\
\hline 6 & $\begin{array}{l}14.0 \\
18.0\end{array}$ & $\begin{array}{l}239.0 \\
248.0 \\
212.0\end{array}$ & $577.40 \dagger$ & 1 & 3 \\
\hline 7 & $\begin{array}{l}4.0 \\
8.0\end{array}$ & $\begin{array}{l}186.0 \\
224.0 \\
204.0\end{array}$ & $301.20 \dagger$ & 1 & 3 \\
\hline
\end{tabular}

* Difference between the nonincubated lots and the incubated lots is within the 99.9 per cent range of significance. $\dagger$ Difference between the nonincubated lots and the incubated lots is within the 99 per cent range of significance.

superficial lipid layer was then removed by suction with a Pasteur pipet. The supernate was frozen at $-20^{\circ} \mathrm{C}$ and kept overnight. The next day it was rapidly thawed at $37^{\circ} \mathrm{C}$ with gentle shaking and centrifuged for 1 hour at $20,000 \mathrm{~g}$ in order to discard the lipoprotein fraction (6). The final supernate was perfectly clear and represents the soluble fraction from each homogenate.

Fibrinogen determination. Standard precipitin curves $(5,13)$ as shown in Figure 2 were established with dilutions of pooled human heparinized plasma ( $2 \mathrm{U}$ heparin per $\mathrm{ml}$ of blood) and of Cohn's fraction I in the heparinized incubation medium. The content of clottable protein of the pooled plasma and of fraction I of Cohn was determined by nitrogen determination, the conversion factor being 6.00 (14).

Measurement of fibrinogen in the soluble fraction of liver homogenate. The antibody solution was thawed and centrifuged for 1 hour at $20,000 \mathrm{~g}$ before use. One $\mathrm{ml}$ was then added to $5 \mathrm{ml}$ of soluble fraction or to $5 \mathrm{ml}$ of the fibrinogen solution (for standard curve, Figure 2). Blanks consisted of antibody solution mixed with saline without antigen. The solutions were immediately and thoroughly mixed, incubated for 1 hour at $37^{\circ} \mathrm{C}$ and overnight at $2^{\circ} \mathrm{C}$. The tubes were sealed with parafilm. According to the method of Gitlin (15), the precipitate resulting from the antibody antigen reaction was centrifuged for 30 minutes at $5^{\circ} \mathrm{C}$ at $3,000 \mathrm{rpm}$, washed three times with cold saline, dissolved in $1 \mathrm{ml}$ of $0.25 \mathrm{~N}$ acetic acid, and again centrifuged at $3,000 \mathrm{rpm}$ for 15 minutes. The optical density of the supernatant protein solution was determined at the wavelength of $278 \mu$ in a Beckman spectrophotometer using micro-quartz cells of $1 \mathrm{~cm}$.

The liver slices of seven individuals were studied in seven incubation experiments. In two of these, in addition to the usual procedure, the incorporation of L-leucine- $\mathrm{C}^{\mathbf{1 4}}$ into the antibody-precipitated protein was measured. This incorporation was studied in order to provide additional evidence of protein synthesis in these experiments. The following procedure was followed: to both incubated and nonincubated flasks $0.1 \mathrm{ml}=0.02$ $\mathrm{mg}$ of L-leucine- $\mathrm{C}^{\mathbf{1 4}}$ was added, corresponding to a radioactivity of $1 \mu \mathrm{c}$. After spectrophotometric reading the protein solution was precipitated with an equal volume of 10 per cent trichloroacetic acid (TCA) saturated with nonradioactive L-leucine. The precipitate was washed twice with 5 per cent TCA, homogenized with a Pottertype homogenizer $(1,000 \mathrm{rpm})$ for one minute and spread on a Millipore filter with a disc diameter of $25 \mathrm{~mm}$ and a pore size of $0.45 \mu$ (Millipore Filter Corp., Bedford, Mass.). Radioactivity was measured according to Heuson (16) on the dry filter in a scintillator (MBLE, Belgium), which counted about 40 per cent of the beta particles emitted from the surface of the filter. Counting at infinite thinness was possible, since the protein content of the TCA-precipitate did not exceed $200 \mu \mathrm{g}$ per sample (no correction for autoabsorption). 
TABLE II

Increase of radioactivity in the antibody-precipitated protein after incubation with L-leucine- $C^{14}$

\begin{tabular}{ccrc}
\hline \hline \multirow{2}{*}{$\begin{array}{c}\text { Experi- } \\
\text { ment }\end{array}$} & \multicolumn{2}{c}{ Counts per minute } & \\
\cline { 2 - 4 } $\begin{array}{c}\text { Nonincu- } \\
\text { bated lots }\end{array}$ & $\begin{array}{c}\text { Incubated } \\
\text { lots }\end{array}$ & $\begin{array}{c}\text { Back- } \\
\text { ground }\end{array}$ \\
\hline 5 & 72.0 & $\begin{array}{r}990.0 \\
74.0\end{array}$ & 77.4 \\
& 84.2 & 115.0 & \\
7 & 68.2 & 523.0 & 74.4 \\
& 72.3 & 610.0 & \\
& & 582.0 & \\
& & & \\
\end{tabular}

\section{RESULTS}

1. Increase of antibody-precipitated protein after incubation of liver slice. Seven experiments were performed with liver slices from seven individuals. The results are shown in Table I. There was an increase in the amount of antibody-precipitated protein at the end of the incubation period in all experiments. This increase was subjected to statistical analysis. ${ }^{1}$ One factor analysis of variance (17) (Table I) demonstrated a highly significant increase of precipitated protein in the experiments $1,4,5,6$, and 7 and an increase which was not significant in the experiments 2 and 3. (The variance per lot being proportional to the means, the registered values have been transformed into logarithmic values for the statical validity test). The average increase was $0.19 \mathrm{mg}$ per $\mathrm{g}$ per 4 hours for the first group of experiments.

2. Incorporation of L-leucine-C $C^{14}$ into antibodyprecipitated protein. In experiments 6 and 7, a marked increase of radioactivity in the precipitate was noted after incubation, when $\mathrm{C}^{\mathbf{1 4}}$-labeled L-leucine had been added to the incubation medium (Table II). The nonincubated lots gave background values.

\section{DISCUSSION}

The low plasma level of fibrinogen found in circulating blood compared to albumin does not implicate a proportionately little production of fibrinogen. Volwiler and associates (18), feeding $\mathrm{S}^{35}$ sulfur or injecting $S^{35}$-labeled proteins into normal subjects, found $t_{1}$ turnover rates of 3.5 days

\footnotetext{
1 I wish to thank Dr. Martin and Miss Lenger, who kindly carried out statistical analysis of the results.
}

for fibrinogen compared to 21.5 days for albumin. These results indicate a considerable production rate of fibrinogen. The results presented here show an increase in protein precipitable by antibodies against human fibrinogen in homogenates prepared from human liver slices plus medium at the end of an incubation period as compared with the amount of the same protein at the beginning of the incubation period.

The antibody solution used in these experiments showed no cross-reaction with serum proteins. With the double-diffusion method of Ouchterlony it showed only one precipitation line with the soluble fraction of liver homogenate. A faint second line in one incubated lot is probably due to an artifact. However, since the absorption of the antiserum with serum does not remove antibodies against certain coagulation factors other than fibrinogen, such as prothrombin, factor $\mathrm{V}$, and factor VIII, which are known to be also consumed during coagulation and to be also produced in the liver, the possibility of another antigen has to be considered. Nevertheless, the extremely small concentration of these proteins in plasma as compared to the concentration of fibrinogen would suggest that cross-reaction with these coagulation factors is negligible. Cross-reactions with tissue proteins appear to be most unlikely in view of the very low control values for the precipitated protein found in nonincubated lots in most experiments. The procedure of immunoprecipitation implies the precipitation of not only fibrinogen, but all soluble proteins having the antigenic properties of fibrinogen. Since split products of proteolysis of fibrinogen preserve the antigenic properties of fibrinogen (19), proteolysis might eventually be responsible for an increase of antibody precipitated protein after incubation. The difference in molecular weight would explain the different degrees of curvature observed in Figure 1A and Figure 1B. Nevertheless, the presence of only one precipitation line in the double-diffusion plate, the increase of the observed magnitude, and the marked incorporation of a radioactive amino acid into the antibody-precipitated protein are evidence against this explanation. In addition, this objection might be addressed also to the works on albumin synthesis. It may be concluded that it is most probable that the increase of antibody-pre- 
cipitated protein means an increase of fibrinogen.

The quantitative differences among the results for the seven individuals have to be attributed to important differences in age, sex, duration of anesthesia, and the basic illness. The insignificant increase in experiments 2 and 3 could be attributed to the following factors. 1) The lots of these experiments were too small. The cutting procedure by hand, which permits some differences in the thickness of the slices and the variability of distribution of fibrous tissue in one liver sample, introduces an error that greatly increases with decreasing size of the lots. Moreover, the error of the protein determination increases when the protein concentration is lowered. 2) Owing to the small amounts of tissue arailable at laparotomy in experiments 2 and 3 . it was not possible to prepare a statistically needed minimal number of lots.

The fact that the liver tissue studied here did not come from normal individuals prevents a generalization of the conclusions reached in this study. The results will have to be confirmed with specimens from normal individuals. Similar experiments with other tissue than liver will also be attempted.

The average rate of fibrinogen increase in vitro may be grossly compared with turnover studies of fibrinogen in vivo. While the biological halflife time of human fibrinogen, recently surveyed by Blombäck, Boström, and Vestermark (20), does not vary greatly from author to author (21, $22,17,8)$, there exist enormous reported differences for the total body pool of fibrinogen, indicating an in vivo production of approximately 5 $\mathrm{g}$ per day (21) and $1.7 \mathrm{~g}$ per day (8). If we base an assumption on the average production in vitro of $0.19 \mathrm{mg}$ per $\mathrm{g}$ per 4 hours found in this study, a liver of $1,500 \mathrm{~g}$ would produce approximately $1.65 \mathrm{~g}$ fibrinogen per day, a quantity which is in the order of magnitude of the in vivo turnover studies.

The results presented appear highly suggestive of the production of fibrinogen by human liver in vitro. Till now, the in vitro formation of serum proteins has been studied on liver slices of laboratory animals. The data presented are, to our knowledge, the first attempt to demonstrate plasma protein production by intact human liver tissue in vitro.

\section{SUMMARY}

After incubation of human liver slices of seven individuals in a heparinized Krebs-Ringer bicarbonate medium, a marked increase was noted of a protein precipitable by specific rabbit antibodies prepared against human fibrinogen. A net increase of radioactivity in the antigen-antibody precipitate was shown when radioactive L-leucine$\mathrm{C}^{14}$ was added to the incubation medium. The results are highly suggestive of fibrinogen production by human liver slices in vitro. This production is in the order of magnitude of the fibrinogen production calculated from in vivo turnover studies.

\section{ACKNOWLEDGMENTS}

I am greatly indebted to Professor Henry Tagnon, Mrs. Andrée Steens, and Dr. J. C. Heuson for invaluable help and assistance; to Dr. J. Lebrun and Dr. W. Mattheiem, who kindly provided liver samples; and to Dr. C. Gompel and Dr. Walbroeck for histological examinations.

\section{REFERENCES}

1. Meek, W. J. Relation of the liver to the fibrinogen content of the blood. Amer. J. Physiol. 1912, 30, 161.

2. Foster, D. P., and Whipple, G. H. Blood fibrin studies. I. An accurate method for the quantitative analysis of blood fibrin in small amounts of blood. Amer. J. Physiol. 1921, 58, 365.

3. Drury, D. R., and McMaster, P. D. The liver as the source of fibrinogen. J. exp. Med. 1929, 59, 569.

4. Miller, L. L., Bly, C. G., Watson, M. L., and Bale, W. F. The dominant role of the liver in plasma protein synthesis. A direct study of the isolated perfused rat liver with the aid of lysine- $\epsilon-C^{14}$. J. exp. Med. 1951, 94, 431.

5. Peters, T., Jr., and Anfinsen, C. B. Net production of serum albumin by liver slices. J. biol. Chem. 1950, 186, 805 .

6. Campbell, P. N. Utilization of glucose for the synthesis of protein in chicken and rat hepatoma in vitro. Biochem. J. 1955, 61, 496.

7. Campbell, P. N., and Stone, N. E. The synthesis of serum albumin and tissue proteins in slices of rat liver and liver tumour. Biochem. J. 1957, 66, 19.

8. Gitlin, D., and Borges, W. H. Studies on the metabolism of fibrinogen in two patients with congenital afibrinogenemia. Blood 1953, 8, 679.

9. Hochwald, G. M., Thorbecke, G. J., and Asofsky, R. Sites of formation of immune globulins and of a component of $\mathrm{C}_{3}^{\prime}$. I. A new technique for the 
demonstration of the synthesis of individual serum proteins by tissues in vitro. J. exp. Med. 114, 459, 1961.

10. Cohen, P. P., in Manometric Techniques, W. W. Umbreit, R. H. Burris, and J. F. Stauffer, Eds. Minneapolis, Burgess, 1957, ch. 9, p. 149.

11. Gitlin, D. J. The localization of homologous plasma proteins in the tissues of young human beings as demonstrated with fluorescent antibodies. J. exp. Med. 1953, 97, 163.

12. Ouchterlony, Ǒ. In vitro method for testing toxinproducing capacity of diphtheria bacteria. Acta path. microbiol. scand. 1948, 25, 186.

13. Heidelberger, M., and Kendall, F. E. The precipitin reaction between type III pneumococcus polysaccharide and homologous antibody. J. exp. Med. 1935, 61, 563.

14. Reiner, M. Fibrinogen in Standard Methods of Clinical Chemistry. 1961, vol. 3.

15. Gitlin, D. Use of ultraviolet absorption spectroscopy in the quantitative precipitin reaction. J. Immunol. 1949, 62, 437.
16. Heuson, J. C., and Legros, N. Etude "in vitro" de l'action des hormones sur le métabolisme des cancers du sein. I. Méthode de mesure. Rev. franç. Etud. clin. biol. 1962, 7, 149.

17. Snedecor, G. W. Statistical Methods. Iowa State College Press, 1956.

18. Volwiler, W., Goldsworthy, P. D., MacMartin, M. P., Wood, P. A., Mackay, I. R., and Fremont-Smith, $\mathrm{K}$. Biosynthetic determination with radioactive sulphur of turn-over rates of various plasma proteins in normal and cirrhotic man. J. clin. Invest. 1955, 34, 1126.

19. Salmon, J. Etude immunochimique du fibrinogène et de ses dérives. Clin. chim. Acta 1959, 4, 767.

20. Blombäck, B., Boström, H., Vestermark, A. On the $\left[{ }^{26} \mathrm{~S}\right]$ sulphate incorporation in fibrinopeptide $B$ from rabbit fibrinogen. Biochim. biophys. Acta (Amst.) 1960, 38, 502.

21. Hammond, J. D. S., and Verel, D. Observations on the distribution and biological half-life of human fibrinogen. Brit. J. Haemat. 1959, 5, 431.

22. Christensen, L. K. The turnover of plasma fibrinogen. Acta med. scand. 1958, 162, 407. 